\title{
Baleen whale distributions and prey associations in the Barents Sea
}

\author{
Mette Skern-Mauritzen*, Edda Johannesen, Arne Bjørge, Nils Øien
}

Institute of Marine Research, 5817 Bergen, Norway

\begin{abstract}
We investigated the spatial associations between minke Balaenoptera acutorostrata, fin B. physalus and humpback Megaptera novaeangliae whales and their prey in the Barents Sea in late summer of 2003 to 2007. During these years the abundance of their assumed primary prey, capelin Mallotus villotus, was low due to a stock collapse. The whales were therefore expected to associate with abundant herring Clupea harengus in the southern Barents Sea and krill (Euphausiacea) in the central and northern Barents Sea. The baleen whales predominantly occupied a narrow, northern area that had high densities of krill, amphipods Themisto spp., and polar cod Boreogadus saida along the northern range of the capelin distribution. A small proportion of the Barents Sea minke and fin whales occurred in the southern areas. Herring was therefore not an important prey species in the Barents Sea in this season. Ecosystem-scale associations, which were determined by spatial associations between species distributions averaged across years, indicated that krill was the predominant prey species. However, contrasting mesoscale associations with their prey in $50 \mathrm{~km}$ grid cells and a preference for shallow northern banks suggests that these whales have a diverse diet within a preferred habitat. Finally, positive density dependence and facilitation can be significant processes that influence whale distributions, as the 3 baleen whale species were positively associated at both ecosystem- and mesoscales.
\end{abstract}

KEY WORDS: Ecosystem survey $\cdot$ Pelagic communities $\cdot$ Trophic interactions $\cdot$ Marine mammals

\section{INTRODUCTION}

The Barents Sea is a high latitude shelf sea with high productivity, low biological diversity and strong species interactions (Wassmann et al. 2006) and has experienced major changes during the past decades, including collapses and subsequent recoveries of Atlantic herring Clupea harengus and capelin Mallotus villosus (Gjøsæter et al. 2009) and, recently, increased water temperatures (Stiansen \& Filin 2008). Because significant top-down regulation of both zooplankton and pelagic fish occurs (Dalpadado et al. 2003, Hjermann et al. 2004, Gjøsæter et al. 2009), toppredator responses to different prey stock regimes determine both the structure and the functioning of this ecosystem.

According to the theory of ideal free distribution (IFD, Fretwell \& Lucas 1970), predators should distrib- ute such that their density relative to prey availability is uniform across the landscape, yielding an equal rate of return (e.g. Millinski \& Parker 1991). This prediction has been termed the 'habitat matching rule' and predicts positive spatial relationships between predators and prey. Minke Balaenoptera acutorostrata, humpback Megaptera novaeangliae and fin whales $B$. physalus are top predators in the Barents Sea. We investigated baleen whale-prey interactions in the Barents Sea by analysing the spatial associations between these species and their potential prey species with late summer (August to September) synoptic distribution data from surveys conducted from 2003 to 2007. These survey years were exceptionally warm, and even the northern areas were free of sea ice and available to pelagic predators in late summer (Stiansen \& Filin 2008). Capelin abundances were low due to a stock collapse in 2002 and 2003 (Gjøsæter et al. 2009), 
while herring and krill (Euphausiacea) were abundant (Gjøsæter et al. 2009, Zhukova et al. 2009). The diet and prey selection of minke whales has been thoroughly studied in early summer (May to June) when the northern Barents Sea is ice-covered (e.g. Haug et al. 2002, Smout \& Lindstrøm 2007). During this season, minke whales in the Barents Sea preferentially forage on capelin, but the dietary importance of herring and krill increases when capelin abundance decreases (Haug et al. 2002, Smout \& Lindstrøm 2007). However, little knowledge exists on minke whale-prey interactions in late summer or on interactions between fin and humpback whales and their prey in this ecosystem.

Minke, fin and humpback whales often congregate in the same feeding areas, likely targeting similar prey (Piatt \& Methven 1992, Murase et al. 2002, Friedlaender et al. 2009, Skern-Mauritzen et al. 2009). In general, they seem to prefer pelagic fish to zooplankton in northern ecosystems (Murase et al. 2007, Smout \& Lindstrøm 2007, Witteveen et al. 2008). However, in comparison with that in early summer, the prey assemblage in late summer (e.g. August to September) may include additional species. Northern areas with high amphipod Themisto spp. (Dalpadado et al. 2001) and polar cod Boreogadus saida (Stiansen \& Filin 2008) densities are exposed so these prey species become

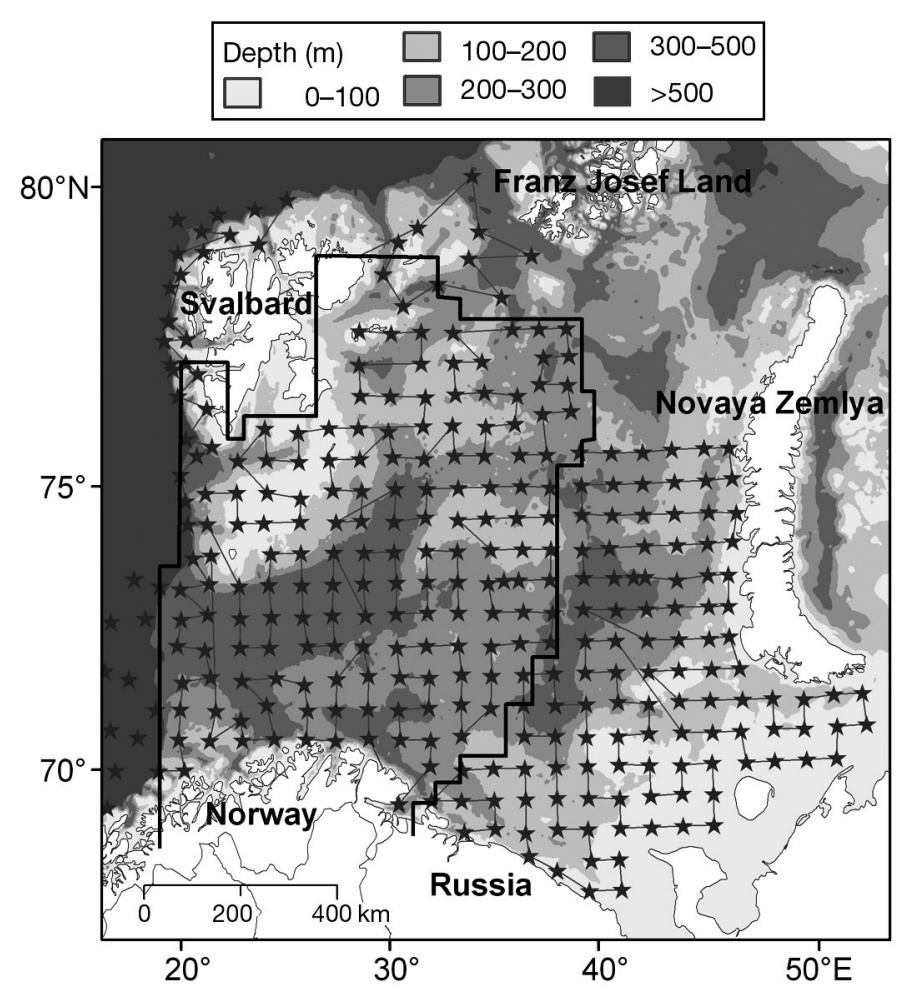

Fig. 1. Barents Sea. Annual ecosystem survey area in 2005. Thick black line: study area. Thin grey lines: transects between stations; and ( $\star$ ): trawl and CTD stations available for pelagic predators following the sea ice retreat. High densities of blue whiting Micromesistius poutassou, a meso-pelagic fish of the Norwegian Sea, also occurred in the southwestern Barents Sea during the survey years (Heino et al. 2008, Dolgov et al. 2010). These species could also be important to baleen whales as prey.

While predators may spatially match their prey at large spatial scales, efficient predator avoidance by prey may reduce the spatial match present at smaller spatial scales. Fauchald \& Erikstad (2002) found a significant spatial match between a top predator species and their prey, guillemots Uria spp. and capelin, respectively, in the Barents Sea on scales $\geq 50 \mathrm{~km}$. We therefore investigated spatial associations between baleen whales and prey at 2 spatial scales: (1) the ecosystem scale by analysing spatial associations between averaged species distributions across years, and (2) the mesoscale by analysing spatial associations between observed whale and prey species densities within $50 \mathrm{~km}$ grid cells. Due to the low capelin abundance, we expected the baleen whales to target alternative prey. If prey preferences in late and early summer were similar, the baleen whales were expected to be foraging on, and spatially match, herring and krill. However, we also assessed the potential importance of amphipods, polar cod, and blue whiting to baleen whales by investigating their spatial associations.

\section{MATERIALS AND METHODS}

Study system and ecosystem survey. The Barents Sea is a relatively shallow (mean depth $230 \mathrm{~m}$ ) shelf sea covering $1600000 \mathrm{~km}^{2}$ (Fig. 1). The central and northern areas, which are dominated by the polar front and cold Arctic water masses, are seasonally covered by ice, while the southern Barents Sea remains free of ice all year due to warm Atlantic water masses (Fig. 2, Wassmann et al. 2006). During the study years mean herring and polar cod abundances (1.52 and 1.28 million $t$, respectively) were above the long-term means, while mean capelin abundance $(0.83$ million $\mathrm{t})$ was well below the long-term mean (Stiansen \& Filin 2008). Mean blue whiting abundance was 0.97 million t (from 2004 to 2007, no abundance estimate is available for 2003, Stiansen \& Filin 2008). No abundance estimates of krill or amphipods were available, but trends in long-term krill indices suggest high krill abundance (Zhukova et al. 2009). About 40000 minke whales (body size 5-15 t), 2000 fin whales (50-70 t) and 700 humpback whales (25-40 t) reside in the Barents Sea in summer (Skaug et al. 2004, Øien 2009).

Data were collected during the 2003-2007 Norwegian-Russian ecosystem surveys, which followed a 

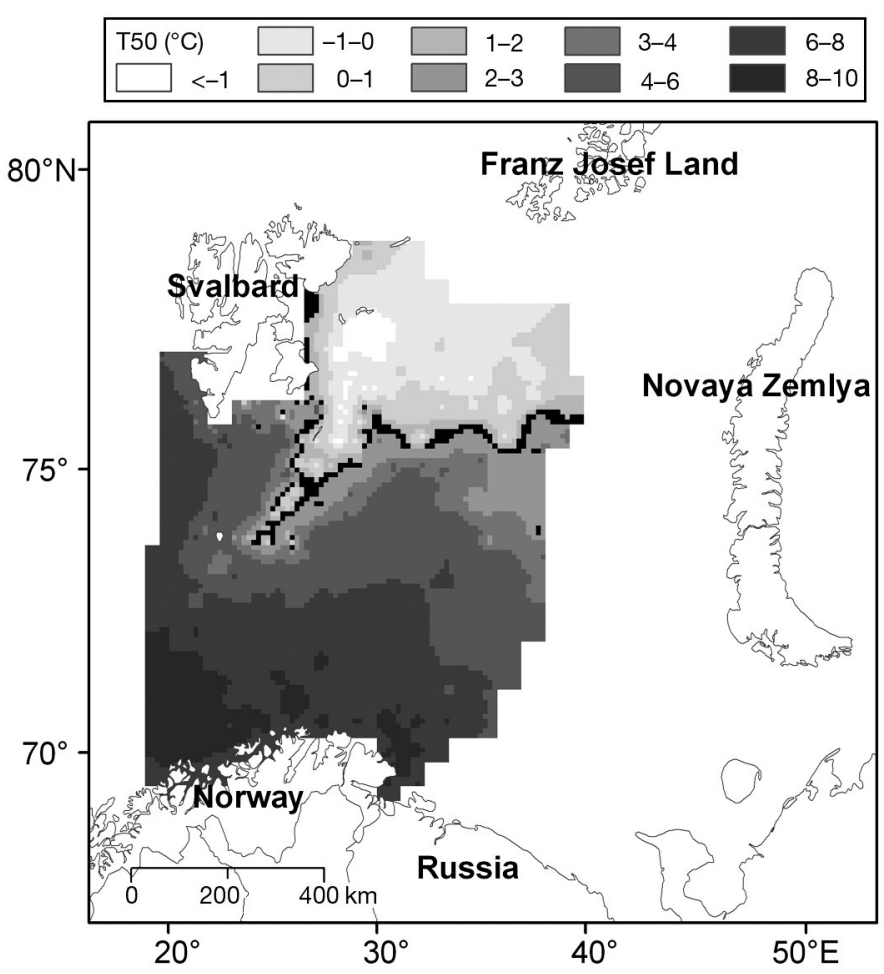

Fig. 2. Position of Arctic $\left(<2^{\circ} \mathrm{C}\right)$ and Atlantic water masses $\left(>2^{\circ} \mathrm{C}\right)$ and the polar front between them (black squares, $\sim 2^{\circ} \mathrm{C}$ ) in the study area in 2005 as determined from water temperature at $50 \mathrm{~m}$ (T50)

regular, predetermined sampling design covering the Barents Sea during 2 mo starting in late July or early August (Fig. 1, Anonymous 2009). At fixed stations 30 to 35 nautical miles apart (Fig. 1), standard CTD casts were made to measure depth-specific temperature. At the same stations, krill and amphipods were caught by trawling with a small mesh 'Harstad' mid-water trawl that had a $20 \mathrm{~m}^{2}$ mouth opening, 7 panels and a cod end. The panels had mesh sizes varying from $100 \mathrm{~mm}$ in the first panel to $30 \mathrm{~mm}$ in the last. The cod end consisted of a $30 \mathrm{~m}$ long capelin net with $20 \mathrm{~mm}$ meshes for catching pelagic fish and a $14 \mathrm{~m}$ long inner net with $7 \mathrm{~mm}$ meshes for catching 0-group fish. The trawl was towed at a speed of 3 knots with the headline at three different depths $(0,20$ and $40 \mathrm{~m})$ for $0.5 \mathrm{n}$ miles at each depth. Age and species composition of pelagic fish and species composition and density of 0-group fish were determined for fish caught in the trawls. The larger zooplankton such as krill and amphipods that were caught in the inner net were used as density indices in the analyses of the spatial distribution of zooplankton. Trawls were conducted systematically throughout the study area from 2005 to 2007 , with the exception of no trawling north of $77^{\circ} \mathrm{N}$ in 2003 and 2004 .

Along the transects between stations (Fig. 1), 2 marine mammal observers on the vessel's bridge each scanned a visual sector of $45^{\circ}$ from the front to the port and starboard side, respectively, and noted the positions of all marine mammals observed. During the first 3 yr the marine mammal observers participated on vessels covering the western part the ecosystem only, thereby limiting the area included in this study (Fig. 1) but still covering the main baleen whale distributions within the Barents Sea (Anonymous 2009). The observers also recorded visibility and Beaufort sea state (BSS) continuously.

Pelagic fish distributions were surveyed acoustically along transects with calibrated SIMRAD EK-60 echo sounders at frequencies of 18, 38, 120 and $200 \mathrm{kHz}$ (Anonymous 2009). Bergen Echo Integrator (BEI, Korneliussen 2004) and Large Scale Survey System (LSSS, Korneliussen et al. 2006) software were used to postprocess the acoustic signals in 2004 and 2005 and 2006 and 2007, respectively. During post-processing, experienced personnel allocated the acoustic backscattering to species based on characters of the acoustic signals and the species and size compositions of the trawl catches. Acoustic species densities were finally expressed as the area backscattering coefficient $\mathrm{s}_{\mathrm{A}} \mathrm{m}$ $\mathrm{n}$ mile $^{-2}$ (i.e. the volume backscattering coefficient integrated over depth and averaged over distance, Korneliussen 2004) and used as a density index in analyses of pelagic fish distributions. In addition to those at fixed stations, trawls were also performed in response to changes in the acoustic signals to validate the allocation of acoustic strengths to species. As these trawls were conducted non-randomly, zooplankton catches from them were not included in any analyses. Furthermore, no acoustic data on zooplankton were available from these surveys due to challenges in acoustical discrimination of species and species groups in mixed swarms (E. Ona pers. comm.).

Data treatment. Effort was determined to be the distance along each transit that observers were scanning for marine mammals. BSS ranged from 1 to 7 and $90 \%$ of the effort was conducted in sea states $\leq 5$. Visibility ranged from $0.4 \mathrm{~km}$ to the horizon. Because adverse sea state conditions reduce the probability of observing whales, dedicated whale sighting surveys generally stop when visibility $<1 \mathrm{~km}$ and BSS $>4$. The multipurpose ecosystem survey continued independent of observer conditions, and we chose to include effort and observations with sea state $\leq 5$ to maintain as many observations in the data set as possible. Removal of data during sea states $>4$ did not change model results in any analyses.

Pelagic fish densities (mean $\mathrm{s}_{\mathrm{A}} \mathrm{m} \mathrm{n}$ mile ${ }^{-2}$ ), whale observer effort and whale counts $(\mathrm{N})$ were averaged and summed in $50 \mathrm{~km}$ grid cells along the cruise tracks. The size of the grid cells matched the resolution of the CTD and zooplankton data approximately, and 
this resolution set the lower scale for the analysis of whale-prey associations. However, scales of $\geq 50 \mathrm{~km}$ have proven to be important in identifying top predator-prey interactions in the Barents Sea (Fauchald \& Erikstad 2002). Zooplankton biomass was standardized for swept area ( $\mathrm{kg} \mathrm{n} \mathrm{mile} \mathrm{e}^{-1}$ ) following Dingsør (2005) and analysed using each trawl as a unit. Bottom depth at each grid cell center and station was obtained from the General Bathymetric Chart of the Oceans (GEBCO) digital atlas (British Oceanographic Data Centre). Temperature at $50 \mathrm{~m}$ (T50) was assigned to each grid cell or station by inverse distance interpolation (power $=2$ ).

Spatial species associations. Spatial associations between the baleen whales and potential prey species were investigated at 2 spatial scales. At the ecosystem scale, we modelled the species' general distributions within the ecosystem averaged across years and assessed the correlation between the modelled distributions. The limited number of whale observations and variable observer coverage between years caused by periods with poor weather conditions prevented the fit of annual distribution models. At the mesoscale, we analysed the whale densities observed in $50 \mathrm{~km}$ grid cells as a response to the observed prey densities observed in the corresponding cells.

(1) Species distribution models: We used General Additive Mixed Models (GAMMs) in the mgcv library (Wood 2006) in R v.2.7.0 (R Development Core Team) to model the averaged species distributions across the study years as a function of physical habitat and $\mathrm{X}$ and Y coordinates. The density $\left(D_{i}\right)$ of each species in sample $i$ (i.e. grid cell or station) was fitted to the different covariates according to the following model:

$$
D_{i}=\mathrm{s}\left(\mathrm{T}_{50}\right)+\mathrm{s}\left(\text { depth }_{i}\right)+\mathrm{s}\left(\mathrm{X}_{i}, \mathrm{Y}_{i}\right)+\operatorname{year}_{i}+e_{i}
$$

where the predictors included the smoothed fits (s) of T50 and the depth of sample $i$ and the 2-dimensional smoothing function for the geographical location of sample $i$ in the $\mathrm{X}$ (longitudinal) and Y (latitudinal) direction. Year was entered as a random variable, while $e_{i}$ denotes the error for sample $i$. Whale counts were used as the response in quasi Poisson models scaled for moderate overdispersion (scale parameters $<6$, Zuur et al. 2009) with effort for each grid cell (km) as an offset. Visibility and BSS were included as additional covariates to correct for observation conditions. Pelagic fish and zooplankton densities were used as responses in normal models. Transformation of the densities was needed due to skewed distributions. The best transformations, determined from data plotting, were found to be $\log _{10}$ (for pelagic fish densities) after adding constants of 0.1 (polar cod) or 1 (all other fish species) and (zooplankton)^ 0.2 . Because the trawls did not cover the vertical distribution of the zooplankton completely, diurnal migrations resulted in nocturnal zooplankton catches that were greater than those during the day. Therefore, a bivariate dummy variable added to the zooplankton models to correct for time of sampling. Night was defined to be between sunset and sunrise, and day was defined to be between sunrise and sunset. Zooplankton distribution models run with night samples only gave similar distribution patterns to those including both day and night samples when adjusted for time of sampling. Also, the krill distribution in this study was comparable to the distributions based on samples of the complete water column observed by Zhukova et al. (2009) from October to December in the corresponding years. No diurnal effects were observed in the acoustic densities of pelagic fish, as these densities are integrated across the water column. The selected distribution models were used in the predict.gam function of the mgcv package to predict the general averaged distributions across years onto a grid with $50 \mathrm{~km}$ resolution.

(2) Spatial associations between whales and prey: We entered the predicted averaged species distributions into a principal component analysis (PCA) to assess the spatial associations between baleen whales and their prey species at the ecosystem scale. PCA is a multivariate analysis used for exploring correlations between variables in a multivariate dataset. More specifically, it is a mathematical procedure that uses an orthogonal transformation to convert a set of observations of more or less correlated variables into a set of values of uncorrelated variables, the principal components (PCs). The variance explained by the PCs and the association between each initial variable and the PCs (expressed as loadings) were used to interpret the correlation structure between the species distributions. Species with similar spatial distributions would thus have similar loadings on the PCs and would be positioned together in a biplot, in which the loadings were plotted relative to the $\mathrm{PC}$ axes.

Spatial associations at the mesoscale were assessed by using the observed whale counts (N) for each $50 \mathrm{~km}$ grid cell as responses to observed habitat and prey densities in those cells with the following GAMM model:

$$
\begin{aligned}
\mathrm{N}_{i}= & \text { Visibility }+ \text { BSS }+\mathrm{s}\left(\mathrm{T}_{50}\right)+\mathrm{s}\left(\text { depth }_{i}\right)+ \\
& \sum_{m} \mathbf{s}_{m}\left(P_{m i}\right)+\text { year }_{i}+e_{i}
\end{aligned}
$$

where $P_{m i}$ denotes the density of prey species $m$ in sample $i$. Observer effort $(\mathrm{km})$ was included as an offset. Year was entered as a random variable, while $\mathrm{e}_{i}$ denotes the error for sample $i$.

Model selection and validation. The best models were identified by removing the non-significant variables $(\mathrm{p}>0.05)$ in a backward selection procedure. Particularly when data were sparse, as for the baleen 
whales, the GAMM tended to produce overly fit curves reflecting local patterns. We therefore limited the number of dimensions to 5 for all model terms, except for the $\mathrm{s}(\mathrm{X}, \mathrm{Y})$ term, to focus on the general, large-scale patterns. The optimal degree of smoothing was defined by Generalized Cross Validation (Wood 2006).

Residuals were plotted for assessing distributions and influential outlying observations to validate the models. Variance inflation factors (VIFs) were estimated to check for colinearity, where VIFs $<5$ suggest no colinearity (Heiberger \& Holland 2004). We estimated spatial correllograms on both the observed data and the residuals from the distribution and species association models to assess spatial autocorrelation in the data and model residuals.

\section{RESULTS}

Annual distances surveyed by the marine mammal observers within the study area ranged from 3431 to
$7528 \mathrm{~km}$. A total of 762 baleen whales were observed within the study area, consisting of 260 fin whales, 239 humpback whales and 263 minke whales. Relative to the abundance, the proportion of minke whale observations was lower than for fin and humpback whales. Minke whales are the most inconspicuous of these whales.

\section{Species distributions}

Statistical results from the species distribution models are given in Tables 1-3, while the predicted averaged distributions are shown in Fig. 3. The VIFs showed that T50 and latitudinal position were confounded (VIF > 5, all other VIFs < 3.5). The smoothed geographical position was generally highly significant, showing that bathymetry and temperature alone did not sufficiently describe the species distributions. T50 was mostly significant and was therefore kept in the models despite its colinearity with latitudinal position

Table 1. Euphausiacea and Themisto spp. Results of fixed effect models for zooplankton density distributions determined from zooplankton density $\left(\mathrm{kg} \mathrm{n}\right.$ mile $\left.^{-1}\right)$. Year was included as a random variable. T50: water temperature at $50 \mathrm{~m}$ depth; X, Y: geographic coordinates. edf: estimated degrees of freedom. ${ }^{*} \mathrm{p}<0.05,{ }^{* *} \mathrm{p}<0.01,{ }^{* * *} \mathrm{p}<0.001$, ns: non-significant

\begin{tabular}{|c|c|c|c|c|c|c|c|c|c|c|c|c|c|}
\hline \multirow[t]{2}{*}{ Predictor } & \multicolumn{3}{|c|}{ __ Day/Night __ } & \multicolumn{3}{|c|}{ Depth } & \multicolumn{3}{|c|}{$-\mathrm{T} 50$} & \multicolumn{3}{|c|}{$-\mathrm{X}, \mathrm{Y}$} & \multirow{2}{*}{ Adj. $R^{2}$} \\
\hline & df & $F$ & $\mathrm{p}$ & edf & $F$ & $\mathrm{p}$ & edf & $F$ & $\mathrm{p}$ & edf & $F$ & $\mathrm{p}$ & \\
\hline Krill & 1 & 144.5 & $* * *$ & 1 & 1.54 & ns & 1 & 0.74 & ns & 10.23 & 3.63 & $* * *$ & 0.17 \\
\hline Amphipods & 1 & 8.60 & $* *$ & 1 & 2.42 & ns & 3.11 & 22.48 & $* * *$ & 20.95 & 10.08 & $* * *$ & 0.51 \\
\hline
\end{tabular}

Table 2. Boreogadus saida, Mallotus villosus, Clupea harengus and Micromesistius poutassou. Results of fixed effect models for pelagic fish density distributions determined from mean acoustic density $\left(\mathrm{s}_{\mathrm{A}} \mathrm{m} \mathrm{n}\right.$ mile ${ }^{-2}$ ). Year was included as a random variable.

T50: temperature at $50 \mathrm{~m}$ depth; $\mathrm{X}, \mathrm{Y}$ : geographic coordinates. ${ }^{*} \mathrm{p}<0.05,{ }^{* *} \mathrm{p}<0.01,{ }^{* * *} \mathrm{p}<0.001$, ns: non-significant

\begin{tabular}{|c|c|c|c|c|c|c|c|c|c|c|}
\hline \multirow[t]{2}{*}{ Predictor } & \multicolumn{3}{|c|}{ Depth -} & \multicolumn{3}{|c|}{$-\mathrm{T} 50-$} & \multicolumn{3}{|c|}{$-\mathrm{X}, \mathrm{Y}-$} & \multirow[t]{2}{*}{ Adj. $R^{2}$} \\
\hline & edf & $F$ & $\mathrm{p}$ & edf & $F$ & $\mathrm{p}$ & edf & $F$ & $\mathrm{p}$ & \\
\hline Polar cod & 3.70 & 36.60 & $* * *$ & 3.33 & 12.97 & $* * *$ & 23.95 & 21.48 & $* * *$ & 0.56 \\
\hline Capelin & 3.57 & 10.35 & $* * *$ & 3.43 & 23.58 & $* * *$ & 26.48 & 22.69 & $* * *$ & 0.37 \\
\hline Herring & 1 & 3.02 & ns & 3.21 & 6.83 & $* * *$ & 19.28 & 10.37 & $* * *$ & 0.37 \\
\hline Blue whiting & 3.88 & 3.88 & $* * *$ & 3.53 & 6.95 & *** & 24.45 & 31.21 & *** & 0.73 \\
\hline
\end{tabular}

Table 3. Balaenoptera acutorostrata, B. physalus and Megaptera novaeangliae. Results of fixed effect models for baleen whale distributions determined from the number of whales observed per $50 \mathrm{~km}$ grid cell. Observer effort (km surveyed in each grid cell) was set as an offset, and year was included as a random factor. BSS: Beaufort sea state; T50: water temperature at $50 \mathrm{~m}$ depth; $\mathrm{X}, \mathrm{Y}$ : geographic coordinates. ${ }^{*} \mathrm{p}<0.05,{ }^{* *} \mathrm{p}<0.01,{ }^{* * *} \mathrm{p}<0.001$, ns: non-significant

\begin{tabular}{|c|c|c|c|c|c|c|c|c|c|c|c|c|c|c|c|}
\hline \multirow[t]{2}{*}{ Predictor } & \multicolumn{3}{|c|}{ — Visibility - } & \multicolumn{3}{|c|}{$-\mathrm{BSS}-$} & \multicolumn{3}{|c|}{$\longrightarrow$ Depth -} & \multicolumn{3}{|c|}{- T50 -} & \multicolumn{2}{|c|}{$-\mathrm{X}, \mathrm{Y}-$} & \multirow[t]{2}{*}{ Adj. $R^{2}$} \\
\hline & $\mathrm{df}$ & $F$ & $\mathrm{p}$ & $\mathrm{df}$ & $F$ & $\mathrm{~Pa}$ & edf & $F$ & $\mathrm{p}$ & edf & $F$ & $\mathrm{p}$ & edf $\quad F$ & $\mathrm{p}$ & \\
\hline Minke whale & 1 & 6.04 & * & 1 & 0.11 & ns & 1 & 6.50 & * & 2.44 & 2.27 & ns & 10.572 .21 & * & 0.11 \\
\hline Fin whale & 1 & 0.03 & ns & 1 & 3.38 & $*$ & 1.48 & 3.54 & 0.04 & 1.49 & 0.65 & ns & 14.354 .56 & $* * *$ & 0.31 \\
\hline Humpback whale & 1 & 2.93 & ns & 1 & 0.91 & ns & 1 & 0.01 & ns & 1 & 1.93 & ns & 16.122 .66 & $* * *$ & 0.21 \\
\hline
\end{tabular}




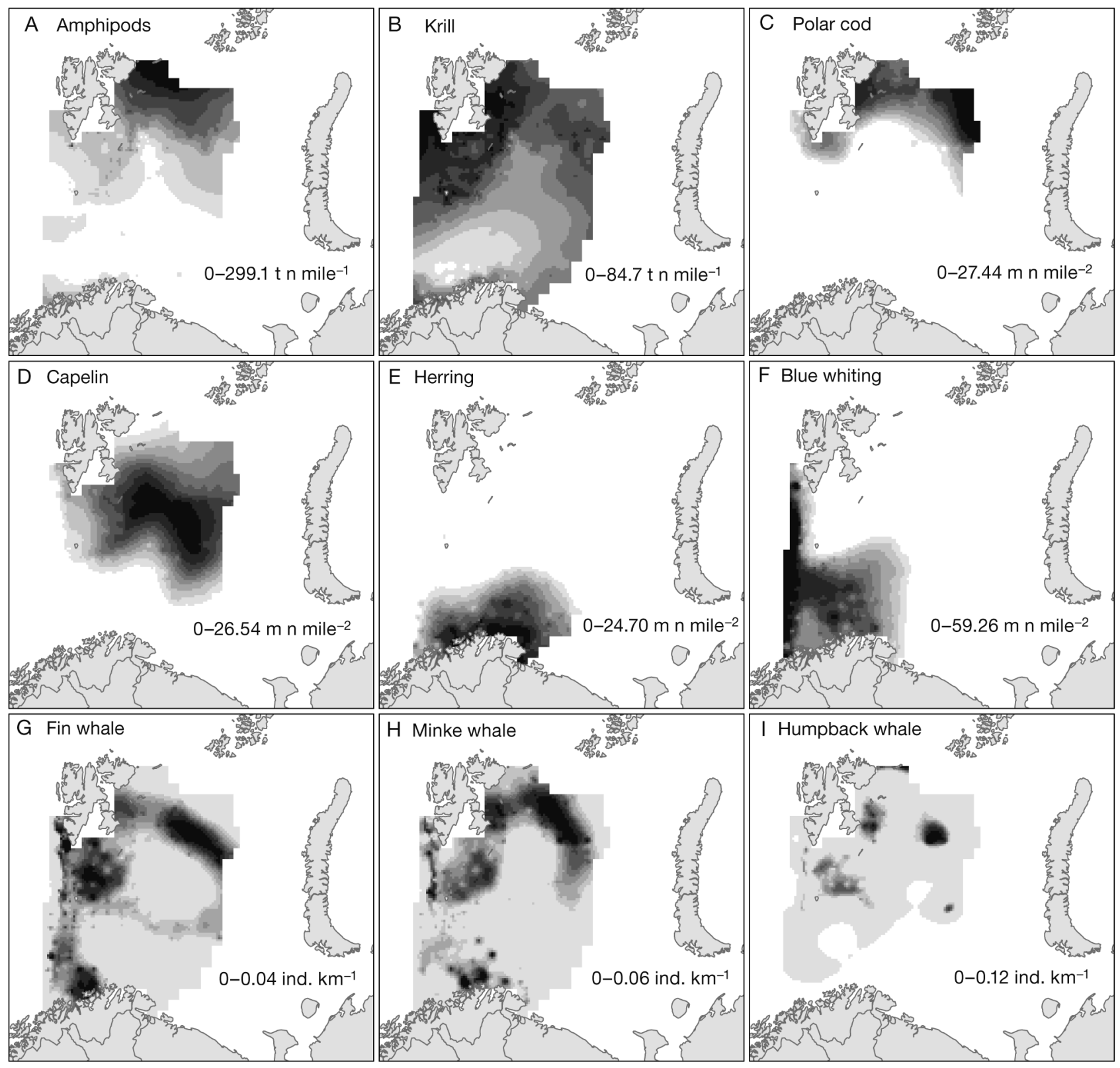

Fig. 3. Predicted mean species distributions across years from GAMM models with year as a random factor and temperature and depth as predictors. Range of predicted values (grey shading) for each species for 2005 is shown. (A,B) Zooplankton: mean catch in $\mathrm{t} n$ mile ${ }^{-1}$ trawled. (C-F) Pelagic fish: mean acoustic back scatter coefficient $\mathrm{s}_{\mathrm{A}} \mathrm{m} n \mathrm{mile}{ }^{-2}$. (G, $\left.\mathrm{H}_{1} \mathrm{I}\right) \mathrm{Baleen}$ whales: mean ind. $\mathrm{km}^{-1}$, assuming a $10 \mathrm{n}$ mile visibility and Beaufort sea sta

to increase the precision of the modelled distributions. However, the colinear variables complicated any interpretation of whale habitat use. We therefore chose to use the whale-prey association models to elucidate whale habitat use because no variables were confounded in these models (see 'Spatial associations between whales and prey', below).

The krill and amphipod distribution models ( $\mathrm{N}=925$ stations) accounted for 17 and $51 \%$ of the variation in krill and amphipod densities, respectively. Both krill and amphipod densities were highest in the north (Fig. 3A,B), but while amphipods were predominantly limited to the polar front and northwards (Fig. 3A), krill were widely distributed (Fig. 3B). The pelagic fish distribution models accounted for 37 to $73 \%$ of the variation $(\mathrm{N}=1060$ grid cells), and their distributions were geographically segregated (Fig. 3C-F). Polar cod inhabited the northern Arctic water masses (Fig. 3C), 

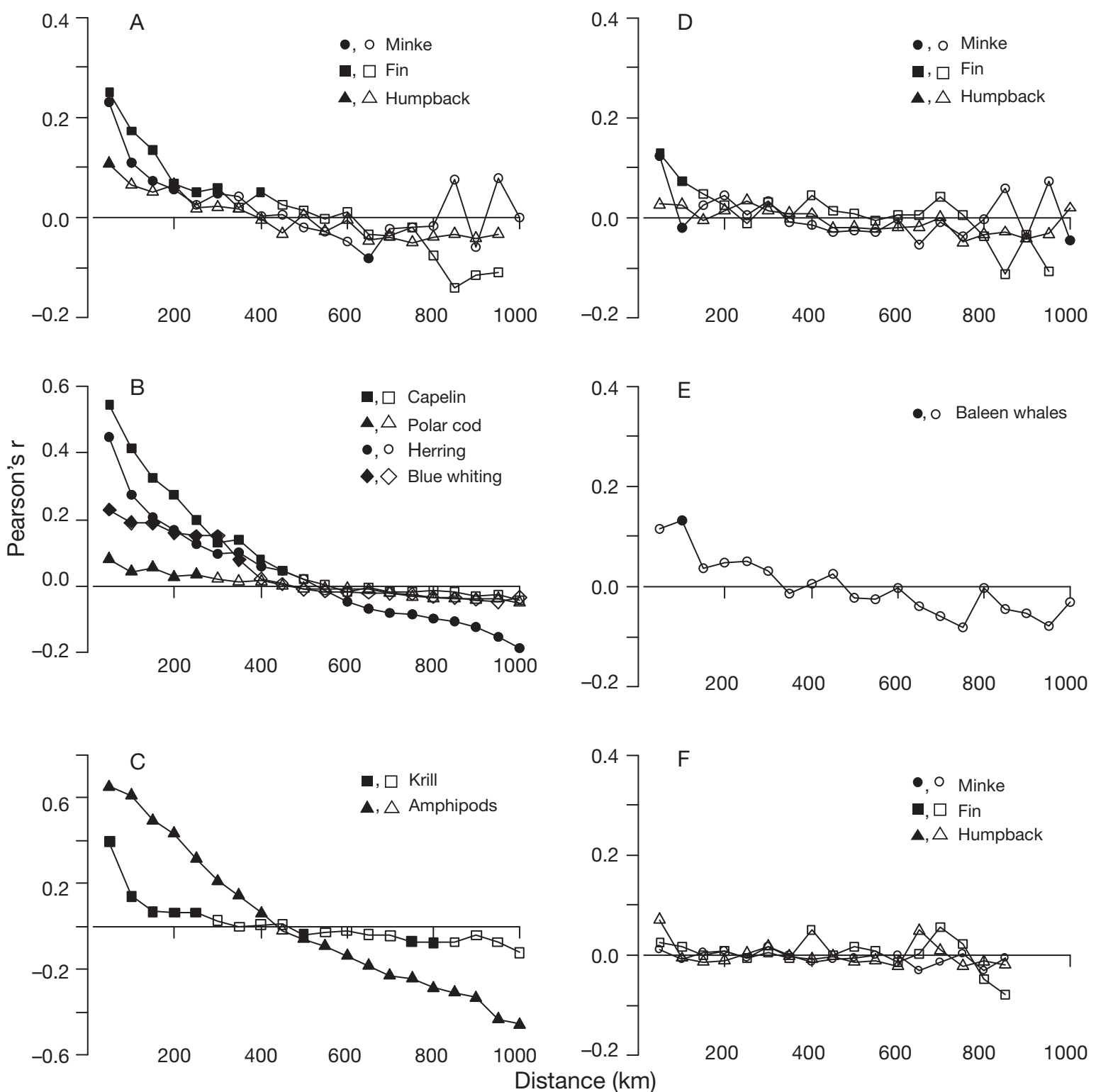

Fig. 4. Spatial correlations for baleen whales, pelagic fish and zooplankton. Correllograms were estimated from raw data summed in $50 \mathrm{~km}$ grid cells (whales and pelagic fish, A,B) or at stations (zooplankton, C) or from residuals of whale distribution (D), whale-zooplankton association (E) and whale-pelagic fish association (F) models. Significance levels were Bonferronicorrected for the number of distance classes $(\mathrm{N}=20)$. Filled symbol: significant at $\mathrm{p} \leq 0.0025$; open symbol: non-significant

while capelin was distributed along the polar front (Fig. 3D). Herring inhabited southern Atlantic water masses (Fig. 3E) and was overlapped by blue whiting, which inhabited the southwestern areas towards the western shelf break (Fig. 3F). The baleen whale distribution models accounted for 11 to $31 \%$ of the variation ( $N=647$ grid cells). BSS and visibility varied in significance within these models (Table 3). Lack of significance may be due to the use of averaged observation conditions within the grid cells, reducing the precision of these variables. Also, whales were observed across the range of the included observation conditions, as the concentrated high density areas were in both good and poorer conditions. The 3 baleen whale species had similar and overlapping distributions. They occupied a narrow northern zone along and north of the polar front (Fig. 3G-I). Limited numbers of the fin and minke whales also inhabited the shelf edge and the southwestern Barents Sea (Fig. 3G,H).

Spatial corellograms based on the gridded data (whales and pelagic fish) and trawls (zooplankton) demonstrated a significant spatial correlation between nearby observations, which diminished and became significantly negative as distance between the obser- 
vations increased (Fig. 4A-C). The scales of the extent of the species distributions are demonstrated by the distance at which the correlations approach zero. The scales of the distributions were relatively similar across trophic levels, although whale and zooplankton distributions were slightly narrower than those of pelagic fish. The correlations became non-significant at around $300-400 \mathrm{~km}$ for the baleen whales and zooplankton and $400-500 \mathrm{~km}$ for pelagic fish (Fig. 4A-C). The correlation structure in the residuals (Fig. 4C) showed that the distribution model had removed significant amounts of autocorrelation in the whale data set. However, some autocorrelation was left in the residuals, showing that small-scale whale aggregations were not accounted for by these models.

\section{Spatial associations between whales and prey}

At the ecosystem scale, the PCA performed on the averaged distributions suggested 3 geographic species groups (Fig. 5). The first principal component (PC1) separated the distributions of the southern prey species (herring and blue whiting) from the northern ones (polar cod, krill and amphipods, Fig. 5). Along the PC1 axis, the baleen whales were associated with the northern prey species. PC2 separated the centrally located capelin, which were not correlated with any other species, from the southern herring and blue whiting. Along the PC2 axis, fin whales were associated with herring and blue whiting due to some fin whales inhabiting the southwestern part of the study region. PC1 and PC2 accounted for 55 and $18 \%$ of the variation in the dataset, respectively.

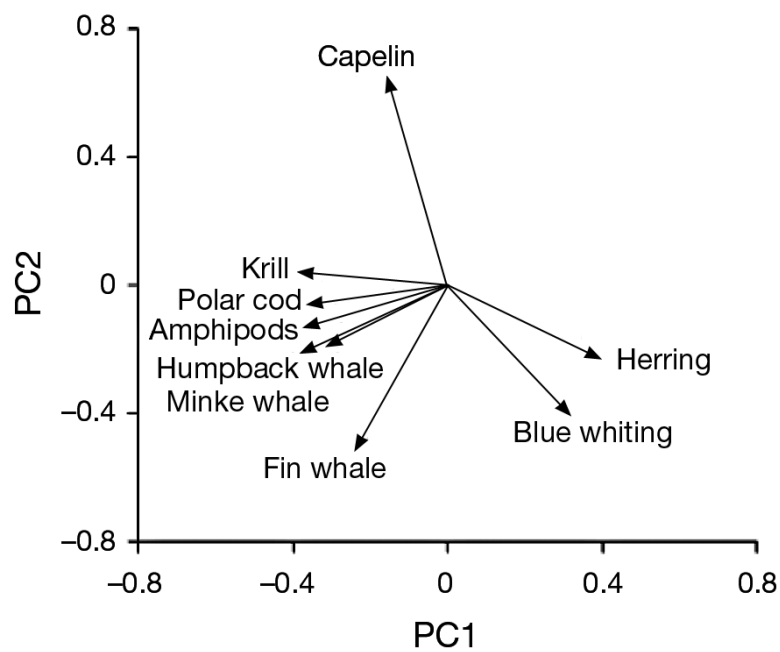

Fig. 5. Ecosystem-scale associations between whales and different prey species. Results of principal component analysis (PCA) based on the predicted species distributions averaged across years
A total of 435 trawls with whale observer effort $>0$ within a range of $25 \mathrm{~km}$ were included in the analysis of mesoscale whale-zooplankton associations. However, due to the northern baleen whale distributions and lack of trawls in the northernmost areas in 2003 and 2004, whales were observed within $25 \mathrm{~km}$ from only 58 of those trawls. The spatial match between the pelagic fish and whale datasets was better; a total of 591 grid cells included both acoustic measurements of pelagic fish and whale observer effort, and baleen whales were observed in 158 cells. We therefore chose to run separate analyses for whale-zooplankton and whale-pelagic fish mesoscale associations. Also, due to the low number of whale observations from trawl stations, the number of baleen whales was pooled across whale species in the whale-zooplankton analysis. The use of a pooled response variable was justified by both the overlapping whale distributions at the ecosystem scale (Fig. 3), and a significant positive correlation among the whale species at the mesoscale (Pearson's $r=0.19-0.30$, all $p<0.001$ ). In the GAMM model, the baleen whale density was not associated with krill or amphipod densities, only with T50 and depth (Table 4). Plotting model residuals separately for each baleen whale species against krill and amphipod densities suggested no species-specific associations with zooplankton. None of the predictors were confounded (all VIFs $<1.98$ ), but some spatial autocorrelation was left in the residuals (Fig. 4E).

Mesoscale associations with pelagic fish were modelled for each whale species separately (Table 5). Furthermore, due to the good data coverage of these models and no confounding predictor variables (all VIFs $<2.54$ ), whale habitat use was interpreted from these models. All 3 whale species demonstrated a non-linear association with polar cod, with the highest whale den-

Table 4. Balaenoptera spp., Euphausiacea and Themisto spp. Mesoscale spatial associations between baleen whales and zooplankton determined from the number of baleen whales observed within $25 \mathrm{~km}$ of trawls. Observer effort (km surveyed in each $50 \mathrm{~km}$ grid cell) was set as an offset, and year was included as a random factor. BSS: Beaufort sea state; T50: water temperature at $50 \mathrm{~m}$ depth. edf: estimated degrees of freedom. ${ }^{*} \mathrm{p}<0.05,{ }^{* *} \mathrm{p}<0.01,{ }^{* * *} \mathrm{p}<0.001$, ns: non-significant

\begin{tabular}{|c|c|c|c|}
\hline \multirow{2}{*}{ Predictor } & \multicolumn{3}{|c|}{ _Baleen whales } \\
\hline & edf & $F$ & $\mathrm{p}$ \\
\hline Visibility & 1 & 0.37 & ns \\
\hline BSS & 1 & 0.97 & ns \\
\hline Depth & 2.39 & 2.40 & $*$ \\
\hline $\mathrm{T} 50$ & 3.19 & 4.05 & $* * *$ \\
\hline Krill & 1 & 0.22 & ns \\
\hline Amphipods & 3.19 & 1.81 & ns \\
\hline Adj. $\mathrm{R}^{2}$ & 0.25 & & \\
\hline
\end{tabular}


Table 5. Balaenoptera acutorostrata, B. physalus and Megaptera novaeangliae. Mesoscale spatial associations between baleen whales and pelagic fish determined from the number of whales observed in $25 \mathrm{~km}$ grid cells. Observer effort ( $\mathrm{km}$ surveyed in each $50 \mathrm{~km}$ grid cell) was set as an offset, and year was included as a random factor. BSS: Beaufort sea state; T50: water temperature at $50 \mathrm{~m}$ depth. edf: estimated degrees of freedom. ${ }^{*} \mathrm{p}<0.05,{ }^{* *} \mathrm{p}<0.01,{ }^{* * *} \mathrm{p}<$ 0.001, na: no overlap occurred between these species, ns: non-significant

\begin{tabular}{|c|c|c|c|c|c|c|c|c|c|}
\hline \multirow{2}{*}{ Predictor } & \multicolumn{3}{|c|}{ Minke whales } & \multicolumn{3}{|c|}{ Fin whales } & \multicolumn{3}{|c|}{ Humpback } \\
\hline & edf & F & $\mathrm{p}$ & edf & $F$ & $\mathrm{p}$ & edf & $F$ & $\mathrm{p}$ \\
\hline Visibility & 1 & 3.18 & ns & 1 & 1.13 & ns & 1 & 0.02 & ns \\
\hline BSS & 1 & 7.39 & $* * *$ & 1 & 3.54 & ${ }^{*}$ & 1 & 0.06 & ns \\
\hline Depth & 1 & 13.62 & $* * *$ & 2.5 & 20.31 & $* * *$ & 1 & 28.64 & $* * *$ \\
\hline T50 & 3.28 & 4.43 & $* * *$ & 3.27 & 3.29 & ${ }^{*}$ & 2.51 & 6.34 & $* * *$ \\
\hline Blue whiting & 1 & 13.35 & $* * *$ & 1 & 21.94 & $* * *$ & na & na & na \\
\hline Herring & 1 & 0.18 & ns & 1 & 3.30 & ns & na & na & na \\
\hline Capelin & 2.81 & 3.69 & ${ }^{*}$ & 1.74 & 2.60 & ns & 1 & 5.84 & $* *$ \\
\hline Polar cod & 3.89 & 5.69 & $* * *$ & 1.825 & 9.00 & $* * *$ & 3.88 & 4.00 & ** \\
\hline Adj. $\mathrm{R}^{2}$ & 0.22 & & & 0.15 & & & 0.31 & & \\
\hline
\end{tabular}

whale species had their highest densities in shallow areas and at low temperatures $\left(<2^{\circ} \mathrm{C}\right)$, although fin whales also had high densities in warmer waters around $6^{\circ} \mathrm{C}$ (Fig. 6D). Spatial autocorrelation was nonsignificant in the residuals (Fig. 4F).

\section{DISCUSSION}

All 3 baleen whale species inhabited a narrow zone along and north of the polar front (Fig. 3G-I) in association with shallow and cold water habitats (Fig. 6D,E). Some minke and fin whales also occupied the deeper and warmer western shelf edge and southwestern Barents Sea (Figs. 3 \& 6). The sities at intermediate polar cod densities (Fig. 6A). Similar associations were found between minke whales and capelin, while humpback whales were positively associated with capelin (Fig. 6B). Associations with herring and blue whiting were only tested for minke and fin whales, because no overlap between these southern species and humpback whales was observed (cf. Fig. 3). Minke and fin whales were positively associated with blue whiting but not with herring (Fig. 6C). All 3 baleen southern areas they inhabit in early summer (Haug et al. 2002) were unoccupied, thus clearly demonstrating a seasonal shift in the baleen whale distributions within the Barents Sea ecosystem. The spatial associations at the ecosystem scale, as revealed by the PCA on the averaged species distributions, indicated 3 geographically distinct species groups (Fig. 5). Baleen whales, krill, amphipods and polar cod inhabited the northern areas. Capelin occupied central areas along
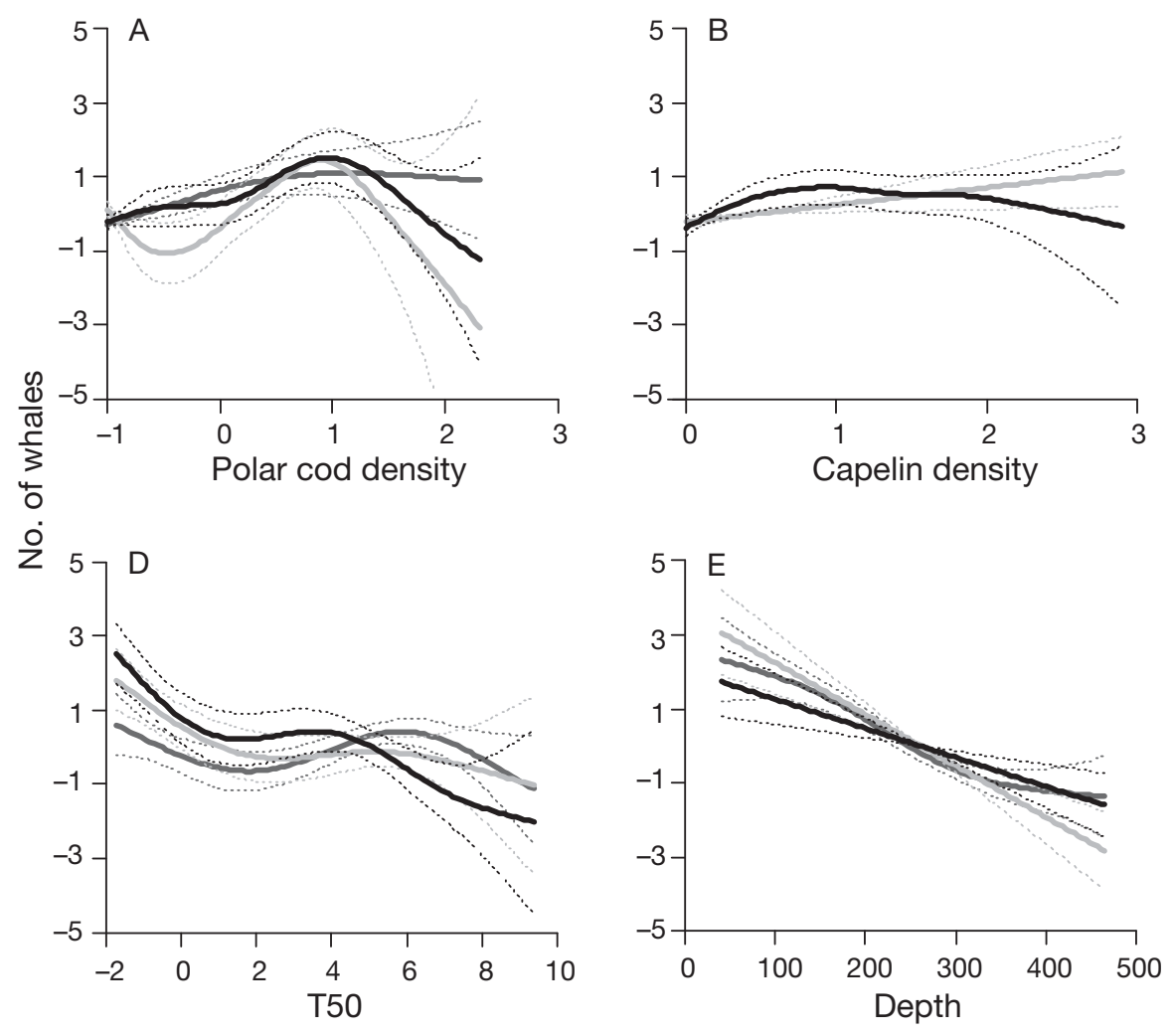

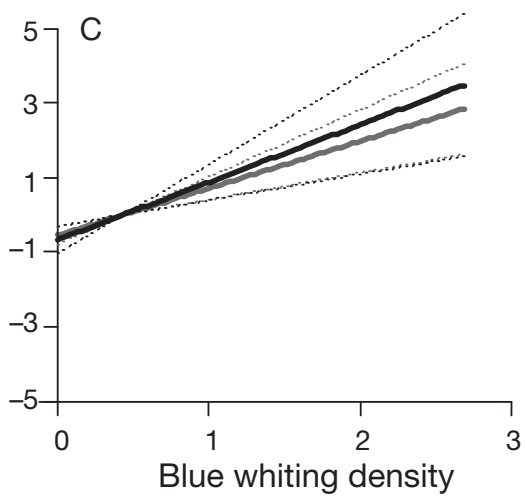

Fig. 6. Mesoscale spatial associations between baleen whales and different prey species and habitat parameters. Predicted deviations from mean minke (thick black line), fin (thick dark grey line), and humpback (thick light grey line) whale densities (number of whales per $50 \mathrm{~km}$ grid cell adjusted for distance surveyed) and \pm SE (thin dotted lines) predicted by selected GAMM models are shown as a function of $(\mathrm{A}-\mathrm{C})$ pelagic fish density $\left[\log _{10}\left(\mathrm{~s}_{\mathrm{A}} \mathrm{m} \mathrm{n} \mathrm{mile}^{-2}\right)\right]$, (D) water temperature at $50 \mathrm{~m}$ depth (T50, $\left.{ }^{\circ} \mathrm{C}\right)$, and (E) depth (m) 
the polar front and was not associated with any other species. Finally, herring and blue whiting occupied the southern areas in association with fin whales. However, the higher densities of all 3 baleen whale species in the north (Fig. 3G-I) demonstrate that the main baleen whale-prey interactions in late summer take place in the north.

\section{Northern baleen whales: krill specialists or generalists?}

According to the PCA, the baleen whales were equally associated with all of the northern prey species: krill, amphipods and polar cod (Fig. 5). However, among these potential prey species, only krill has been reported to be a primary prey of these whales. Also, the similarity between krill and whale distributions (Fig. 3) lends some support to krill as the major prey species for the northern baleen whales. The northward gradient in krill densities (Fig. 3) is likely a product of predation. Their depletion in southern and central areas was greater than that in the north because these areas have been ice free and exposed to pelagic consumers for a longer period of time (Zhukova et al. 2009). Thus, strong top-down control of krill appears to occur even when the capelin abundance is low (Zhukova et al. 2009). The dietary importance of krill for major top predators, such as cod Gadus morhua, harp seals Pagophilus groenlandicus and minke whales, increases in years with low capelin abundance (Nilssen et al. 2000, Haug et al. 2002, Gjøsæter et al. 2009). The northern baleen whale distributions observed in this study could therefore be a response to a late summer predator-mediated krill gradient.

In contrast to associations observed at the ecosystem scale, no positive associations between baleen whales and krill were observed at the mesoscale. This lack of association with krill could be due to imprecise sampling caused by low spatial resolution ( $\sim 30 \mathrm{n}$ mile) and vertical coverage (upper $\sim 60 \mathrm{~m}$ ). Furthermore, krill may alter their vertical position to avoid predators (Onsrud et al. 2004), which could decrease their catchability in the presence of whales. Associations at the mesoscale depend more on individual samples than associations at the ecosystem scale do and may therefore be more sensitive to both sampling errors and prey avoidance behaviour. Nevertheless, the lack of mesoscale associations with krill may signify the importance of scale in whale-prey interactions. Largebodied, homoeothermic baleen whales must eat $1-2 \mathrm{t}$ of zooplankton $\mathrm{d}^{-1}$ to meet their energetic requirements (Kenney et al. 1986), and prey densities must be above critical thresholds for efficient foraging (Piatt \& Methven 1992). High krill densities were observed in the central Barents Sea, where the average density across space and time was lower than in the north. Rather than following single prey patches with the highest densities (e.g. at the mesoscale), whales may inhabit and forage in areas with high prey densities averaged over larger spatial and temporal scales (e.g. at the ecosystem scale) to ensure higher encounter and foraging rates. Hence, prey densities at the ecosystem scale may determine the whale distributions within the ecosystem, as shown by the present study, while significant meso- and finer scale associations are often found in smaller study areas within the distributions of these species (e.g. Witteveen et al. 2008, Hazen et al. 2009, Laidre et al. 2010).

Minke, fin and humpback whales can be considered to be generalist predators, foraging on both zooplankton and pelagic fish (Haug et al. 2002, Piatt \& Methven 1992, Santora et al. 2010, Laidre et al. 2010). In the Barents Sea, whales were associated with shallow northern banks, and they also overlapped with amphipods and polar cod within this habitat (Figs. 3 \& 6). Also, baleen whales occupied the northern rim of the capelin distribution where capelin densities were intermediate (Figs. 3 \& 6). Only humpback whales were positively associated with capelin and only at the mesoscale (Fig. 6). Thus, a variety of prey species were available within the habitat of these whales, although several had intermediate rather than high densities. As these baleen whale species may feed down to about $150 \mathrm{~m}$ (Witteveen et al. 2008, Friedlaender et al. 2009), prey species entering the northern whale habitat may become more available to the whales than in those in the deeper capelin core area (cf. Figs. 1 \& 3). The rather weak spatial mesoscale associations with prey in general could therefore reflect that the whales are targeting a variety of prey species within their habitat, as diet generalists rather than krill specialists.

Unfortunately, the data available to the present study were not suitable to thoroughly assess whether whales were krill specialists or generalists within a preferred habitat. Such an assessment requires tests of additive effects of the different prey species within certain habitat strata on whale densities. However, due to data limitations, the effects of zooplankton and pelagic fish were tested in separate models. The number of zooplankton samples and whale observations was not sufficient to assess any interactions between zooplankton densities and habitat. Finally, distinguishing between these hypotheses may require more fine-scale and continuous acoustic zooplankton recordings along transects. De Robertis et al. (2010) recently used multifrequency acoustic data to discriminate between zooplankton species. Implementing their methods may make acoustic zooplankton data from the Barents Sea ecosystem survey available in the near future. 
The krill specialist-diet generalist hypotheses generate different expectations about the whales' responses to the capelin recovery. Capelin abundance increased from 0.71 million $\mathrm{t}$ in 2006 to 1.89 million $\mathrm{t}$ in 2007 and 4.43 million t in 2008 (Gjøsæter et al. 2009). Increasing capelin abundance generally increases the zooplankton depletion (Dalpadado et al. 2002), propelling a faster and longer northward feeding migration by capelin (Fauchald et al. 2006). Indeed, high capelin densities were found further north in 2008 than in preceding years, stretching further into the northern whale-distribution zone (Anonymous 2009). If whales are preferentially foraging on krill, the capelin increase should prompt a northward whale displacement to maintain their position along the capelin migration front, thereby avoiding areas depleted by capelin. If whales are foraging on various prey species within a preferred habitat, they should maintain their distributions, and the increased capelin immigration would strengthen the mesoscale whale-capelin association within that habitat.

Detailed analyses of baleen whale responses to the return of the capelin must wait for 1 to 2 yr of data collection to ensure good spatial coverage of observation effort and sufficient numbers of whale observations in a capelin-rich situation. However, both in 2007 and 2008 baleen whales were observed within the same narrow distribution zone (Skern-Mauritzen 2009), suggesting a persistent use of these areas independent of capelin abundance. Thus, in warm years with little sea ice, the northern areas may represent rich habitats where the relative availability and importance of different prey species may vary between years depending on their abundance.

\section{Baleen whales and southern prey species}

We expected the whales to forage on the abundant southern herring. At the ecosystem scale, only fin whales were associated with the southern pelagic fish, and at the mesoscale both minke and fin whales were associated with blue whiting but not with herring. Nevertheless, due to the limited distribution overlap, only small numbers of fin and minke whales could prey on the southern pelagic fish (Fig. 3). While herring can be an important prey in early summer (Lindstrøm et al. 2002), the northward seasonal shift in baleen whale distributions inevitably includes a diet shift to northern prey species. Their complex and dynamic schooling behaviour combined with strong predator avoidance responses may reduce the whales' preference for herring when alternative prey are exposed in late summer (Smout \& Lindstrøm 2007). Blue whiting is a common bathypelagic fish in the deep Norwegian Sea, but it has increased in abundance in the southwestern Barents Sea since 2000 (Heino et al. 2008). Entering the shallow shelf may have made them more available within the depth ranges used by baleen whales.

\section{Baleen whale distributions and implications for interspecific competition}

The 3 baleen whale species were positively associated with each other at both ecosystem and mesoscales. They are often observed foraging within the same fine-scale areas (e.g. within 100-1000 m, Murase et al. 2002, Friedlaender et al. 2009). Due to interspecific competition, niche segregation and spatial segregation are expected between ecologically similar species (Schoener 1983). Indeed, some studies have shown evidence of small-scaled niche segregation, such as foraging at different depths in the water column, foraging in different habitats, or targeting prey of different sizes (Murase et al. 2002, Friedlaender et al. 2009). Nevertheless, positive associations could reflect positive density dependence through facilitation. Foraging seabirds locate other foraging seabirds rather than prey patches, as the birds are much more conspicuous than their prey (Mehlum et al. 1998). Baleen whales can also be conspicuous, producing low frequency, long-ranging sounds when in foraging areas at northern latitudes (e.g. Frazer \& Mercado 2000, Clark 2004). Facilitation produces highly aggregated predator distributions and concentrates predation to a selection of prey patches. Many patches will therefore be free from predators, reducing the spatial match between predators and prey at meso- and finer scales (e.g. Heinemann et al. 1989, Fauchald 2009). Positive density dependence destabilizes predator-prey interactions at smaller scales and can have devastating effects on local prey patches (Fauchald 2009). However, due to the narrow, aggregated whale distributions in the Barents Sea ecosystem, large areas with low or no whale predation pressure should serve as prey refuges, stabilizing these interactions.

\section{CONCLUSIONS}

During 2003 to 2007, which was a warm period with few capelin in the ecosystem, minke, fin and humpback whales predominantly foraged in shallow, cold water areas in the northern Barents Sea. Thus, abundant southern pelagic fish did not constitute a major alternative prey source when capelin abundance was low. Spatial associations at the ecosystem scale suggested krill to be the most important prey species. However, at the mesoscale no associations with krill 
were found, and, in general, whale-prey associations were rather weak, which could result from whales targeting a variety of prey species (e.g. krill, capelin, and possibly amphipods and polar cod) within a preferred habitat. While the data available for this study were not sufficient to thoroughly assess whether the baleen whales were krill specialists or generalists in a preferred habitat, preliminary observations of whale responses to the capelin recovery lend support to the generalist hypothesis. The positive associations among the whale species at both ecosystem and mesoscales suggest that facilitation can be a significant process in aggregating foraging baleen whales.

Acknowledgements. We thank P. Fauchald, U. Lindstrøm and G. Bøthun for fruitful and stimulating discussions during the work with this manuscript. We also thank all those involved in data collection during the ecosystem surveys. E. J., A.B. and M.S. acknowledge the financial support of the Norwegian Research Council project 173348/S40. Finally, 3 anonymous referees provided valuable comments that improved the manuscript.

\section{LITERATURE CITED}

Anonymous (2009) Survey report from the joint Norwegian/ Russian ecosystem survey in the Barents Sea AugustOctober 2008, Vol 1. IMR/PINRO Joint Report Series, No. 1

Clark CW (2004) Baleen whale infrasonic sounds: natural variability and function. J Acoust Soc Am 15:2554

Dalpadado P, Borkner N, Bogstad B, Mehl S (2001) Distribution of Themisto (Amphipoda) spp. in the Barents Sea and predator-prey interactions. ICES J Mar Sci 58: 876-895

Dalpadado P, Bogstad B, Gjøsæter H, Mehl S, Skjoldal HR (2002) Zooplankton-fish interactions in the Barents Sea. In: Sherman K, Skjoldal HR (eds) Large marine ecosystems of the North Atlantic-changing states and sustainability. Elsevier, Amsterdam, p 269-291

Dalpadado P, Ingvaldsen R, Hassel A (2003) Zooplankton biomass variation in relation to climatic conditions in the Barents Sea. Polar Biol 26:233-241

> De Robertis A, McKelvey DR, Ressler PH (2010) Development and application of an empirical multifrequency method for backscatter classification. Can J Fish Aquat Sci 67: 1459-1474

Dingsør GE (2005) Estimating abundance indices from the international 0-group fish survey in the Barents Sea. Fish Res 72:205-218

Dolgov A, Johannesen E, Heino M, Olsen E (2010) Trophic ecology of blue whiting in the Barents Sea. ICES J Mar Sci 67:483-493

Fauchald P (2009) Spatial interaction between seabirds and prey: review and synthesis. Mar Ecol Prog Ser 391: 139-151

Fauchald P, Erikstad KE (2002) Scale-dependent predatorprey interactions: the aggregative response of seabirds to prey under variable prey abundance and patchiness. Mar Ecol Prog Ser 231:279-291

Fauchald P, Mauritzen M, Gjøsæter H (2006) Density-dependent migratory waves in the marine pelagic ecosystem. Ecology 87:2915-2924
Frazer LN, Mercado E (2000) A sonar model for humpback whale song. IEEE J Oceanic Eng 25:160-182

Fretwell SD, Lucas HL (1970) On territorial behavior and other factors influencing habitat distribution in birds. I. Theoretical development. Acta Biotheor 19:16-36

Friedlaender AS, Lawson GL, Halpin PN (2009) Evidence of resource partitioning between humpback and minke whales around the western Antarctic Peninsula. Mar Mamm Sci 25:402-415

Gjøsæter H, Bogstad B, Tjelmeland S (2009) Ecosystem effects of the three capelin stock collapses in the Barents Sea. Mar Biol Res 5:40-53

Haug T, Lindstrøm U, Nilssen KT (2002) Variations in minke whale (Balaenoptera acutorostrata) diet and body condition in response to ecosystem changes in the Barents Sea. Sarsia 87:409-422

Hazen EL, Friedlaender AS, Thompson MA, Ware CR, Weinrich MT, Halpin PN, Wiley DN (2009) Fine-scale prey aggregations and foraging ecology of humpback whales Megaptera novaeangliae. Mar Ecol Prog Ser 395:75-89

Heiberger RM, Holland B (2004). Statistical analysis and data display: an intermediate course with examples in S-Plus, $\mathrm{R}$, and SAS. Springer Texts in Statistics. Springer, New York, NY

> Heinemann D, Hunt G, Everson I (1989) Relationships between the distributions of marine avian predators and their prey, Euphausia superba, in Bransfield Strait and southern Drake Passage, Antarctica. Mar Ecol Prog Ser 58:3-16

> Heino M, Engelhard GH, Godø OR (2008) Migrations and hydrography determine the abundance fluctuations of blue whiting (Micromesistius poutassou) in the Barents Sea. Fish Oceanogr 17:153-163

$>$ Hjermann DO, Stenseth NC, Ottersen G (2004) Indirect climatic forcing of the Barents Sea capelin: a cohort effect. Mar Ecol Prog Ser 273:229-238

Kenney RD, Hyman MAM, Owen RE, Scott GP, Winn HE (1986) Estimation of prey densities required by western North Atlantic right whales. Mar Mamm Sci 2:1-13

Korneliussen RJ (2004) The Bergen echo integrator postprocessing system, with focus on recent improvements. Fish Res 68:159-169

Korneliussen RJ, Ona E, Eliassen I, Heggelund Y and others (2006). The large scale survey system-LSSS. Proc 29th Scand Symp Phys Acoust, Ustaoset, Jan 29-Feb 12006. Available at www.marec.no/downloads/proceedingsUstaoset2006_Korneliussen_etal_LSSS.pdf

Laidre KL, Heide-Jørgensen MP, Heagerty P, Cossio A, Bergstrøm B, Simon M (2010) Spatial associations between large baleen whales and their prey in West Greenland. Mar Ecol Prog Ser 402:269-284

Lindstrøm U, Haug T, Røttingen I (2002) Predation on herring, Clupea harengus, by minke whales, Balaenoptera acutorostrata, in the Barents Sea. ICES J Mar Sci 59:58-70

Mehlum F, Hunt G, Decker M, Nordlund N (1998) Hydrographic features, cetaceans and the foraging of thickbilled murres and other marine birds in the northwestern Barents Sea. Arctic 51:243-252

Millinski M, Parker G (1991) Competition for resources. In: Krebs J, Dabies N (eds) Behavioural ecology. An evolutionary approach. Blackwell, Oxford, p 137-168

Murase H, Matsuoka K, Ichii T, Nishiwaki S (2002) Relationship between the distribution of euphausiids and baleen whales in the Antarctic (35 degrees E-145 degrees W). Polar Biol 25:135-145

Murase H, Tamura T, Kiwada H, Fujise Y and others (2007) Prey selection of common minke (Balaenoptera acutoros- 
trata) and Bryde's (Balaenoptera edeni) whales in the western North Pacific in 2000 and 2001. Fish Oceanogr 16:186-201

Nilssen KT, Pedersen OP, Folkow LP, Haug T (2000) Food consumption estimates of Barents Sea harp seals. In: Vikingsson GA, Kapel FO (eds) Minke whales, harp and hooded seals: major predators in the North Atlantic ecosystem, Vol 2. NAMMCO Scientific Publications, Tromsø, p 9-27

Øien N (2009) Distribution and abundance of large whales in Norwegian and adjacent waters based on ship surveys 1995-2001. In: Øien N, Pike D (eds) North Atlantic sighting surveys, counting the whales in the North Atlantic, 1987-2001, Vol 7. NAMMCO Scientific Publications, Tromsø, p 31-48

Onsrud MSR, Kaartvedt S, Rostad A, Klevjer TA (2004) Vertical distribution and feeding patterns in fish foraging on the krill Meganyctiphanes norvegica. ICES J Mar Sci 61: 1278-1290

Piatt JF, Methven DA (1992) Threshold foraging behavior of baleen whales. Mar Ecol Prog Ser 84:205-210

Santora JA, Reiss CS, Loeb VJ, Veit RR (2010) Spatial association between hotspots of baleen whales and demographic patterns of Antarctic krill Euphausia superba suggests size-dependent predation. Mar Ecol Prog Ser 405: 255-269

Schoener TW (1983) Field experiments on interspecific competition. Am Nat 122:240-285

Skaug HJ, Øien N, Schweder T, Bøthun G (2004) Abundance of minke whales (Balaenoptera acutorostrata) in the Northeast Atlantic: variability in time and space. Can J Fish Aquat Sci 61:870-886

Skern-Mauritzen M (2009). Romlig fordeling av sjøpattedyr. In: Sunnanå K, Fossheim M, van der Meeren G (eds)

Editorial responsibility: Michael Castellini,

Fairbanks, Alaska, USA
Forvaltningsplan Barentshavet-rapport fra overvåkingsgruppen. Fisken og Havet 1b:64-65 (in Norwegian)

Skern-Mauritzen M, Skaug H, Øien N (2009) Line transects, environmental data and GIS: cetacean habitat and prey selection along the Barents Sea shelf edge. In: Øien N, Pike D (eds) North Atlantic sighting surveys, counting the whales in the North Atlantic, 1987-2001, Vol 7. NAMMCO Scientific Publications, Tromsø, p 179-200

Smout S, Lindstrøm U (2007) Multispecies functional response of the minke whale Balaenoptera acutorostrata based on small-scale foraging studies. Mar Ecol Prog Ser 341: $277-291$

Stiansen J, Filin AE (2008) Joint PINRO/IMR Report on the state of the Barents Sea ecosystem in 2007, with expected situation and considerations for management, Vol. 1. IMRPINRO Joint Report Series, Institute of Marine Research, Bergen

Wassmann P, Reigstad M, Haug T, Rudels B and others (2006) Food webs and carbon flux in the Barents Sea. Prog Oceanogr 71:232-287

Witteveen BH, Foy RJ, Wynne KM, Tremblay Y (2008) Investigation of foraging habits and prey selection by humpback whales (Megaptera novaeangliae) using acoustic tags and concurrent fish surveys. Mar Mamm Sci 24: $516-534$

Wood SN (2006) Generalized additive models: an introduction with R. Chapman \& Hall/CRC, Boca Raton, FL

Zhukova NG, Nesterova VN, Prokopchuk IP, Rudneva GB (2009) Winter distribution of euphausiids (Euphausiacea) in the Barents Sea (2000-2005). Deep-Sea Res II 56: 1959-1967

Zuur A, Ieno E, Wlaker N, Saveliev A, Smith G (2009) Mixed effects models and extensions in ecology with R. Springer, New York, NY

Submitted: February 16, 2010; Accepted: January 11, 2011 Proofs received from author(s): March 20, 2011 